DOI: $\underline{\text { https://doi.org/10.31933/jemsi.v2i4 }}$

Received: 21 Januari 2021, Revised: 15 Februari 2021 Publish: 11 Maret 2021

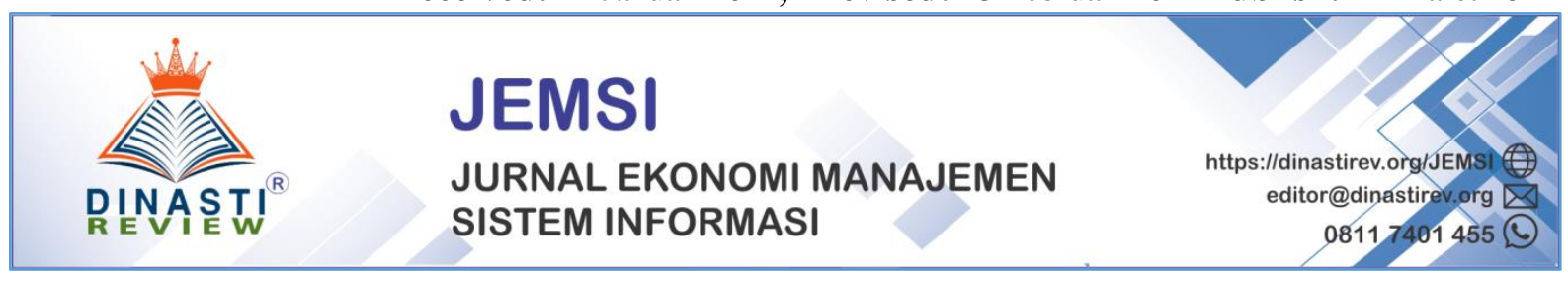

\title{
MODEL MINAT BELI DAN KEPUTUSAN PEMBELIAN IKLAN:PEMASARAN MULTI CHANNELS DAN DISCOUNT DI PORTAL BERITA ONLINE MEDCOM.ID.
}

\author{
Nasikhul Amin Al Hafizi \\ Mahasiswa Program Magister Management, UniversitasMercuBuana, Jakarta. Email: na.alhafizi@gmail.com
}

\section{Corresponding Author: Nasikhul Amin Al Hafizi}

Abstrak:Prariset ini dilakukan bertujuan untuk membangun hipotesis penelitian dengan menggunakan motode kuantitatif, untuk mengetahui variabel yang mempengaruhi minat beli dan keputusan pembelian iklan pada portal berita online medcom.id. Untuk melengkapi pra riset ini, maka peneliti juga melakukan review penelitian terdahulu. Hasil pra riset menunjukkan bahwa diduga pemasaran multi channels dan discount memiliki pengaruh terhadap minat beli dan keputusan pembelian iklan.

Kata Kunci: Pemasaran Multi Channels, Discount, MinatBeli, KeputusanPembelian.

\section{PENDAHULUAN}

Perkembangan teknologi telah merubah banyak pola kehidupan masyarakat, termasuk pola dalam mendapatkan akses informasi.Perkembangan teknologi informasi dan internet melahirkan media baru atau disebut juga media online. Media online merupakan penyederhanaan dari media konvensional dimana merujuk pada perkembangan teknologi digital yang merubah teks, video, grafik dan gambar menjadi data-data digital dalam bentuk byte (Romli, 2012).

Terus meningkatnya belanja iklan (advertising expenditure) yang di putarkan di media online menjadi magnet tersendiri bagi pemilik modal untuk berinvestasi di bisnis media online. Hal ini di tandai dengan lahirnya ribuan situs media online yang tersebar di internet. Berdasarkan data yang dilansir oleh (Dewan Pers, 2017), setidaknya ada 47.300 media online yang saat ini ada di Indonesia.Persaingan antar media online yang begituketatdalam mendapatkan pengiklan merupakan tantangan yang berat bagi perusahaan media karena perusahaan harus mampu menentukan strategi periklanan yang efektif guna memperoleh pemasukan besar dari penjualan iklan.Salahsatu media online yang ikut merasakan ketatnya persaingan di industri media online di Indonesia adalah Medcom.id. 
Secara total pendapatan perusahaan Medcom.id di tahun 2019, terdapat gap antara target dan realisasi pendapatan perusahaan Medcom,id. Perusahaan Medcom.id hanya berhasil merealisasikan $74 \%$ dari target perusahaan.Dalam usaha pencapaian target perusahaan, Medcom.id melakukan berbagai usaha untuk menarik minat beli iklan (beriklan) paraadvertisers di Medcom.id.

Berdasarkan hasil wawancara yang peneliti lakukan pada tim sales Medcom.id, setidaknya ada 10 faktor yang mempengaruhi minat beriklan para advertiser di Medcom.id, diantaranya : Posisi Medcom.id sebagai media online yang berada satu group dengan Metro $\mathrm{TV}$, konten yang berkualitas, portal berita berskala nasional, harga yang kompetitif, diskon/ saving value yang menarik, layanan boosting content, hubungan yang baik antara klien dengan tim Medcom.id, pemasaran multi channels, page view yang relatif besar dibandingkan kompetitor, dan impression yang tinggi.

Untuk mengetahui faktor-faktor mana saja yang paling berpengaruh pada minat membeli iklan (beriklan) di Medcom.id, peneliti melakukan pra survey terhadap 15 orang tim sales Media Group News (MG News) dengan kriteria khusus (purposive sampling) yaitu tim sales MG News yang memiliki klien pernah membeli/ memasang iklan di Medcom.id.Menurut (Arikunto, 2006) purposive sampling adalah sample di lakukan dengan cara mengambil subjek bukan berdasarkan strata, random atau daerah tetapi berdasarkan atas adanya tujuan tertentu. Sampling dengan kriteria khusus ini di harapkan dapat memberikan nilai yang lebih representatif bagi penelitian ini.

Dari pra survey yang dilakukan, peneliti mendapatkan 2 faktor utama yang meningkatkan minat beriklan advertiser di Medcom.id yang di tunjukkan dengan perolehan skor tertinggi. Skor tertinggi no. 1 adalah faktor strategi pemasaran multi channels engan skor 63 Point.Untuk skor tertinggi nomor 2 adalah faktor diskon dengan skor 62 point.

\section{Tabel 1. Pra Riset}

\begin{tabular}{|c|c|c|c|c|c|c|c|c|c|c|c|c|c|c|c|c|c|c|c|}
\hline \multirow{2}{*}{ No. } & \multirow{2}{*}{ Pernyataan } & \multicolumn{15}{|c|}{ Responden } & \multirow{2}{*}{ Total } & \multirow{2}{*}{ Rank } & \multirow{2}{*}{ RANKING } \\
\hline & & 1 & 2 & 3 & 4 & 5 & 6 & 7 & 8 & 9 & 10 & 11 & 12 & 13 & 14 & 15 & & & \\
\hline 1 & Satu group dengan Metro TV & 4 & 4 & 5 & 4 & 3 & 3 & 5 & 4 & 4 & 4 & 4 & 4 & 5 & 4 & 5 & 62 & 2 & 2 \\
\hline 2 & Konten-konten yang berkualitas & 4 & 4 & 3 & 4 & 3 & 4 & 3 & 4 & 5 & 5 & 4 & 4 & 4 & 4 & 5 & 60 & 6 & 6 \\
\hline 3 & Harga yang kompetitif & 4 & 5 & 4 & 4 & 3 & 4 & 4 & 4 & 5 & 4 & 4 & 4 & 4 & 3 & 4 & 60 & 6 & 7 \\
\hline 4 & Diskon/ saving value yang menarik & 3 & 5 & 5 & 4 & 3 & 4 & 5 & 5 & 5 & 4 & 4 & 3 & 4 & 3 & 5 & 62 & 2 & 3 \\
\hline 5 & Layanan boosting content & 3 & 3 & 4 & 4 & 3 & 4 & 4 & 5 & 4 & 5 & 4 & 3 & 3 & 3 & 4 & 56 & 8 & 8 \\
\hline 6 & Portal berita berskala nasional & 4 & 4 & 5 & 4 & 3 & 4 & 4 & 4 & 4 & 4 & 4 & 4 & 4 & 4 & 5 & 61 & 5 & 5 \\
\hline 7 & Hubungan yang baik dengan tim medcom.id & 3 & 5 & 5 & 4 & 3 & 4 & 4 & 5 & 5 & 4 & 4 & 3 & 4 & 4 & 5 & 62 & 2 & 4 \\
\hline 8 & Pemasaran Multi Platform/Multi Channels & 4 & 5 & 5 & 4 & 3 & 4 & 5 & 4 & 5 & 4 & 4 & 4 & 4 & 4 & 4 & 63 & 1 & 1 \\
\hline 9 & Page views relatif lebih besar di bandingkan kompetitor & 4 & 3 & 3 & 3 & 2 & 3 & 3 & 4 & 3 & 4 & 4 & 3 & 3 & 3 & 4 & 49 & 10 & 10 \\
\hline & Impression yang tinggi & 4 & 3 & 4 & 3 & 2 & 3 & 3 & 4 & 3 & 4 & 4 & 3 & 3 & 4 & 5 & 52 & 9 & 9 \\
\hline
\end{tabular}

Hasil Pra Survey Faktor Yang Mempengaruhi Minat Beli Iklan Di Medcom.id 2020

Menurut (Kotler, P. \& Keller, 2009) dalam (Stojković et al., 2016) menjelaskan pemasaran multi channels merupakan situasi dimana sebuah perusahaan mengunakan dua atau lebih saluran untuk menjangkau satu atau lebih segmen pasar. 
Discount adalah penyesuaian harga dasar untuk memberikan pengharaan pada pelanggan atas reaksi-reaksi tertentu, seperti pembayaran tagihan lebih awal, volume pembelian, dan pembelian di luar musim (Philip Kotler, 2007).

Berdasarkan studi dari beberapa penelitian terakhir menyatakan bahwa ada gap penelitian yang perlu diperhatikan terkait minat beli dan keputusan pembelian, seperti yang kemukakan oleh (Rahma, 2007), (Mahendrayasa, 2014)yang menyatakan terdapat hubungan yang signifikan dan positif antara minat beli terhadap keputusan pembelian. Namun, hal berbeda di ungkapkan oleh (Montjai, O., Tewal, B., \& Lengkong, 2014) dalam penelitiannya mengatakan minat beli tidak berpengaruh secara parsial terhadap keputusan pembelian.

Gap penelitian juga ditemukan terkait pengaruh diskon terhadap keputusan pembelian. Menurut (Endhar Widjaya Putra, 2014) mengatakan bahwa diskon berpengaruh tidak signifikan terhadap keputusan pembelian, semantara itu di lain pihak seperti yang dikemukakan oleh (Dewi \& Kusumawati, 2018) menyatakan diskon atau potongan harga berpengaruh positif signifikan terhadap Keputusan pembelian.

\section{Rumusan Masalah}

Berdasarakan latar belakang yang telah diuraikan di atas, maka di rumuskan masalah yang akan di bahas untuk lebih fokus pada kajian pustaka, hasil dan pembahasan adalah sebagai berikut:

1. Bagaimana pengaruh discount terhadap minat pembelian iklan pada media online Medcom.id?

2. Bagaimana pengaruh pemasaran multi channels terhadap minat pembelian iklan pada media online Medcom.id?

3. Bagaimana pengaruh discount terhadap keputusan pembelian iklan pada media online Medcom.id?

4. Bagaimana pengaruh pemasaran multi channels terhadap keputusan pembelian iklan pada media online Medcom.id?

5. Bagaimana pengaruh minat pembelian terhadap keputusan pembelian iklan pada media online Medcom.id?

\section{KAJIAN PUSTAKA \\ Minat Beli}

Menurut(Mowen, 1987) mengatakan bahwa minat beli merupakan penentu dari pembeli untuk melakukan suatu tindakan seperti membeli suatu produk atau jasa. Penelitian tentang minat beli telah banyak dikaji dalambukudanpenelitian sebelumnya seperti bukubukudanpenelitian yang dikembangkan oleh (Ardiansyah, 2012), (Rivan Kojongian, Joyce Lapian, 2019), (P. and G. A. Kotler, 2012), (Yunita \& Ali, 2017), (Ali, 2019a),(Brata et al., 2017), (Anggita \& Ali, 2017b), (Thanh Nguyen et al., 2019), (Novansa \& Ali, 1926), (Mappesona et al., 2020)(Ali, Evi, et al., 2018), and (Ali, Narulita, et al., 2018a)dll.

\section{KeputusanPembelian}

Menurut (Setiadi, 2003) mendefinisikan suatu keputusan (decision)melibatkan pilihan diantara dua atau lebih alternatif tindakan atau perilaku.(Kotler Philip \& Armstrong, 2008) 
menerjemahkan keputusan pembelian sebagai sebuah proses dimana konsumen mengenal masalahnya, mencari informasi mengenai produk atau merek tertentu dan mengevaluasi seberapa baik masing-masing alternatif tersebut dapat memecahkan masalahnya yang kemudian mengarah kepada keputusan pembelian.Penelitian tentangkeputusanpembelian telah banyak dikaji dalambukudanpenelitian sebelumnya seperti buku-bukudanpenelitian yang dikembangkan oleh(Richardo et al., 2020), (Ali, Evi, et al., 2018), (Ikhsani \& Ali, 2017), (Ali, Evi, et al., 2018), (Mappesona et al., 2020), (Novansa \& Ali, 2017), (Thanh Nguyen et al., 2019), dll.

\section{Multi Channel Marketing}

Menurut (Balter, 2015)multi channel marketing adalah strategi untuk menjangkau prospek dan pelanggan melalui berbagai macam platform atau saluran komunikasi.(Kotler, P. \& Keller, 2009) dalam (Stojković et al., 2016) mendefinisikan pemasaran multi channels sebagai situasi di mana "sebuah perusahaan menggunakan dua atau lebih saluran pemasaran untuk mencapai satu atau lebih banyak segmen pasar".Penelitianmulti channel marketingjugatelahbanyak di kajipadapenelitianterdahulusepertipenelitian yang dilakukanoleh(Rangaswamy, A. \&Van Bruggen, 2005), (Chen, 2015), (Schijns \& Nederland, 2014), (Hobmeier, 2001), (Ph. Kotler, 2000), (Rollo, 2004), (Schögel, M. and Sauer, 2002), (Kelly, 2004), (Rollo, 2004)(Schögel, M. and Sauer, 2002), (Easingwood, C. and Storey, 1996)(Ph. Kotler, 2000)(Schögel, M. and Sauer, 2002), (Pucci et al., 2019).

\section{Discount}

(Philip Kotler, 2007) menjelaskan diskon/ potongan harga adalah penyesuaian harga dasar untuk memberikan penghargaan pada pelanggan atas reaksi-reaksi tertentu seperti, waktu pembayaran yang lebih awal, tingkat serta jumlah pembelian dan pembelian pada musim tertentu.Penelitiantentangdiscount/ saving valuejugatelahbanyak di kajipadapenelitianterdahulusepertipenelitian yang dilakukanoleh(Sundalangi et al., 2014), (Citra Kunia putri dan trisna insan Noor, 2013), (Dewi \& Kusumawati, 2018), (Suharno \& Yudi Sutarso, 2010).

\section{METODE PENELITIAN}

Metode penulisan artikel ilmiah ini menggunakan studi literatur dan studi kepustakaan. Dengan mengkaji berbagai referensi sesuai dengan teori yang dibahas, khusunya dalam lingkup Manajemen Pemasaran. Disamping itu menganalisis artikel-artikel ilmiah yang bereputasi dan juga artikel ilmiah dari jurnal yang belum bereputasi. Semua artikel ilmiah yang di citasi bersumber dari Mendeley, Scholar Google, dan Library Mercu Buana.

\section{PEMBAHASAN}

\section{Pengaruh Multi-Channels / Multi Platform Terhadap Minat Beli.}

Pemanfaatan toko online dan offline dapat mempengaruhi minat pembelian pada konsumen (Verhagen \& van Dolen, 2009). Hal serupa juga di ungkapkan pada penelitian (Pucci et al., 2019) yang menyatakan penggunaan beragam media online (social media) menunjukkan peranan penting dalam proses pembelian, serta peggunaan media yang efektif akan dapat membantu peningkatan penjualan. 
Hubungan atau pengaruh variabel multi-channels terhadap minat beli ini sejalan dengan artikel sebelumnya di antaranya, adalah: (Desfiandi, Desfiandi, et al., 2017), (Richardo et al., 2020), (Yunita \& Ali, 2017), (Ali, 2019a),(Brata et al., 2017), (Anggita \& Ali, 2017b), (Thanh Nguyen et al., 2019), (Novansa \& Ali, 1926), (Mappesona et al., 2020)(Ali, Evi, et al., 2018), and (Ali, Narulita, et al., 2018a). (Ali, 2019a), and (Sivaram et al., 2020), (Bimaruci et al., 2020).

\section{Pengaruh Discount Terhadap Minat Beli}

Pada penelitiannya (Sundalangi et al., 2014), menyatakan bahwa potongan harga berpengaruh terhadap minat beli konsumen. Hal serupa di sampaikan oleh (Citra Kunia putri dan trisna insan Noor, 2013), potongan harga/ discount berpengaruh positif dan signifikan terhadap minat beli konsumen. Semakin besar potongan harga, maka semakin besar pula minat beli konsumen.

Hubungan atau pengaruh variabel discount terhadap minat beli ini sejalan dengan artikel sebelumnya di antaranya, adalah: (Desfiandi, Desfiandi, et al., 2017), (Richardo et al., 2020), (Yunita \& Ali, 2017), (Ali, 2019a),(Brata et al., 2017), (Anggita \& Ali, 2017b), (Thanh Nguyen et al., 2019), (Novansa \& Ali, 1926), (Mappesona et al., 2020)(Ali, Evi, et al., 2018), and (Ali, Narulita, et al., 2018a). (Ali, 2019a), and (Sivaram et al., 2020), (Bimaruci et al., 2020).

\section{Pengaruh Multi-Channels Terhadap Keputusan Pembelian}

Pada penelitian (Pucci et al., 2019) yang menyatakan penggunaan beragam media online (sosial media) menunjukkan peranan penting dalam proses pembelian, serta peggunaan media yang efektif akan dapat membantu peningkatan penjualan. Dengan kata lain penggunaan beragam sosial media secara positif berpengaruh pada keputusan pembelian konsumen yang akhirnya terlihat pada peningkatan penjualan.

Hubungan atau pengaruh variabel multi channels terhadap keputusan pembelian ini sejalan dengan artikel sebelumnya di antaranya, adalah: (Ikhsani \& Ali, 2017), (Ali, Narulita, et al., 2018b), (Brata et al., 2017), (Ikhsani \& Ali, 2017), (Ali, 2019b), (Yunita \& Ali, 2017), (Mappesona et al., 2020), (Novansa, Hafizh, Ali, 2017), (Sivaram et al., 2020), (Richardo et al., 2020). (Richardo et al., 2020), (Ali, Evi, et al., 2018), (Ikhsani \& Ali, 2017), (Ali, Evi, et al., 2018), (Mappesona et al., 2020), (Novansa \& Ali, 2017), (Thanh Nguyen et al., 2019).

\section{Pengaruh Discount Terhadap Keputusan Pembelian}

Pada hasil penelitian yang dilakukan oleh (Dewi \& Kusumawati, 2018) dan (Ghristian, 2016) menyatakan variabel diskon berpengaruh secara signifikan terhadap keputusan pembelian. Semakin banyak harga diskon yang ditawarkan maka akan meningkatkan daya beli konsumen.

Hubungan atau pengaruh variabel discount terhadap keputusan pembelian ini sejalan dengan artikel sebelumnya di antaranya, adalah: (Richardo et al., 2020), (Ali, Evi, et al., 2018), (Ikhsani \& Ali, 2017), (Ali, Evi, et al., 2018), (Mappesona et al., 2020), (Novansa \& Ali, 2017), (Thanh Nguyen et al., 2019). (Ikhsani \& Ali, 2017), (Ali, Narulita, et al., 2018b), (Brata et al., 2017), (Ikhsani \& Ali, 2017), (Ali, 2019b), (Yunita \& Ali, 2017), (Mappesona et al., 2020), (Novansa, Hafizh, Ali, 2017), (Sivaram et al., 2020), (Richardo et al., 2020), 


\section{Pengaruh Minat Beli Terhadap Keputusan Pembelian.}

Pembahasan tentang minat beli tidak dapat dipisahkan dari keputusan pembelian. Keputusan pembelian merupakan reaksi lebih lanjut dari minat beli. (Mowen, 1987) mengatakan bahwa minat beli merupakan penentu dari pembeli untuk melakukan suatu tindakan seperti membeli suatu produk atau jasa.

Hubungan atau pengaruh variabel Minat Beli terhadap keputusan pembelian ini sejalan dengan artikel sebelumnya di antaranya, adalah: (Richardo et al., 2020), (Ali, Evi, et al., 2018), (Ikhsani \& Ali, 2017), (Ali, Evi, et al., 2018), (Mappesona et al., 2020), (Novansa \& Ali, 2017), (Thanh Nguyen et al., 2019). (Ikhsani \& Ali, 2017), (Ali, Narulita, et al., 2018b), (Brata et al., 2017), (Ikhsani \& Ali, 2017), (Ali, 2019b), (Yunita \& Ali, 2017), (Mappesona et al., 2020), (Novansa, Hafizh, Ali, 2017), (Sivaram et al., 2020), (Richardo et al., 2020),

\section{Conceptual Framework}

Dengan melihat hubungan antar variabel pada hasil review penelitian sebelumnya sebagai dasar dalam membangun kerangka konseptual, seperti yang di perlihatkan pada Gambar berikut ini.

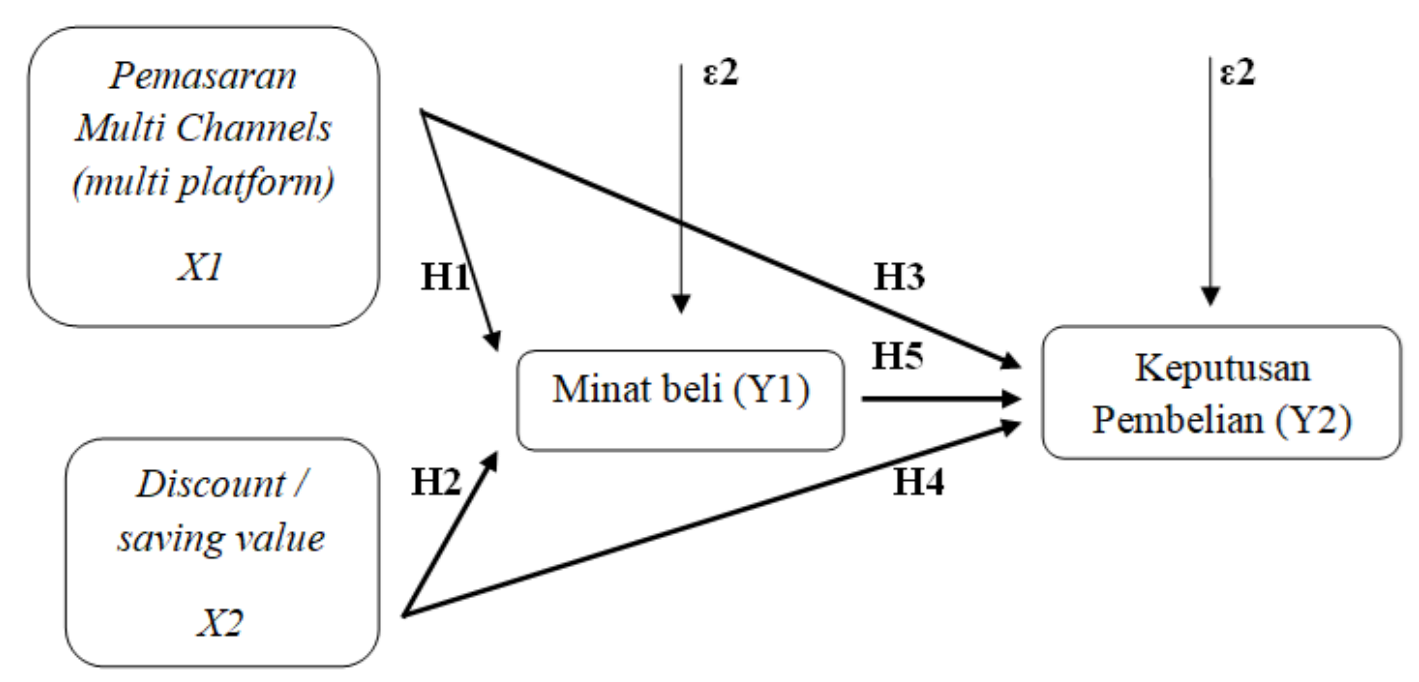

\section{Gambar: Conceptual Framework}

BerdasarkanKajianteoridan review hasildariartikel yang relevansertagambardari conceptual framework, maka:multi channelsdandiscount memiliki hubungan dan berpengaruh terhadap minat belidankeputusanpembelian.

Selain dari multi channels dan discount memiliki yang mempengaruhi minat beli dan keputusan pembelian masih banyak faktor lain, diantaranya adalah:

1) Harga: (Christina Catur Widayati et al., 2020), and (C.C. Widayati et al., 2020), (Ali, Narulita, et al., 2018b), (Ikhsani \& Ali, 2017), (Richardo et al., 2020), (Brata et al., 2017), (Anggita \& Ali, 2017a), (Novansa \& Ali, 2017).

2) Kualitasproduk: (Desfiandi, Fionita, et al., 2017), (M \& Ali, 2017), (Ali, Narulita, et al., 2018a), (M \& Ali, 2017), (Ali, Evi, et al., 2018), (Prihartono \& Ali, 2020), (Riyanto et al., 
2017), (Maisah \& Ali, 2020), (Brata et al., 2017), (Thanh Nguyen et al., 2019), (Ali, 2019b), and (Anggita \& Ali, 2017b).

3) Kualitaslayanan: (M \& Ali, 2017), (Limakrisna \& Ali, 2016), (Yunita \& Ali, 2017), (Yunita \& Ali, 2017), (Ali \& Mappesona, 2016), (Ali, Evi, et al., 2018), (Sitio \& Ali, 2019), and (Anggita \& Ali, 2017b).

4) Citra Merek: (Ali et al., 2016), (M \& Ali, 2017), (Ali \& Mappesona, 2016), (Ali, Narulita, et al., 2018a), (Novansa \& Ali, 1926), and (Toto Handiman \& Ali, 2019).

5) Environment: (Desfiandi, Desfiandi, et al., 2017), (Richardo et al., 2020), (Yunita \& Ali, 2017), (Ali, 2019a),(Brata et al., 2017), (Anggita \& Ali, 2017b), (Thanh Nguyen et al., 2019), (Novansa \& Ali, 1926), (Mappesona et al., 2020)(Ali, Evi, et al., 2018), (Ali, Narulita, et al., 2018a).

6)

\section{KESIMPULAN DAN SARAN}

\section{Kesimpulan}

Berdasarkan rumusanartikel, hasil dan pembahasan yang di kaji dan di bahas pada artikel ini, maka dapatdi rumuskan hipotesis untuk riset selanjutnya:

1. Pemasaran multi channels memiliki hubungan \& berpengaruh terhadap minat beli.

2. Discount memiliki hubungan \& berpengaruh terhadap minat beli.

3. Pemasaran multi channels memiliki hubungan \& berpengaruh terhadap keputusan pembelian.

4. Discount memiliki hubungan \& berpengaruh terhadap keputusan pembelian.

5. Minat beli memiliki hubungan \& berpengaruh terhadap keputusan pembelian.

\section{Saran}

Bersdasarkan Kesimpulan di atas, maka saran pada artikel ini baik secara akademik atau secara empirik adalah masih banyak faktor lain yang mempengaruhi minat beli dankeputusanpembelianiklan. Oleh karena itu, masih di perlukan kajian yang lebih lanjut untuk melengkapi faktor-faktor lain apa sajakah yang dapat memepengaruhi minat belidankeputusanpembelianiklan..

\section{DAFTAR PUSATAKA}

Ali, H. (2019a). Building Repurchase Intention and Purchase Decision: Brand Awareness and Brand Loyalty Analysis (Case Study Private Label Product in Alfamidi Tangerang). Saudi Journal of Humanities and Social Sciences. https://doi.org/10.36348/sjhss.2019.v04i09.009

Ali, H. (2019b). Purchase Decision and Repurchase Models: Product Quality and Process Analysis (Case Study of House Ownership Credit Financing in Permata Sharia Bank Jakarta). Scholars Bulletin. https://doi.org/10.36348/sb.2019.v05i09.006

Ali, H., Evi, N., \& Nurmahdi, A. (2018). The Influence of Service Quality , Brand Image and Promotion on Purchase Decision at MCU Eka Hospital. Business and Management Studies. https://doi.org/10.21276/sjbms.2018.3.1.12

Ali, H., Limakrisna, N., \& Jamaluddin, S. (2016). Model of customer satisfaction: The empirical study at Bri in Jambi. International Journal of Applied Business and Economic Research.

Ali, H., \& Mappesona, H. (2016). Build brand image: Analysis Service Quality and Product 
Quality (case study at Giant Citra Raya). International Journal of Economic Research. Ali, H., Narulita, E., \& Nurmahdi, A. (2018a). Saudi Journal of Business and Management Studies ( SJBMS ) The Influence of Service Quality, Brand Image and Promotion on Purchase Decision at MCU Eka Hospital. Business and Management Studies. https://doi.org/10.21276/sjbms.2018.3.1.12

Anggita, R., \& Ali, H. (2017a). The Influence of Product Quality, Service Quality and Price to Purchase Decision of SGM Bunda Milk. Scholars Bulletin. https://doi.org/10.21276/sb

Anggita, R., \& Ali, H. (2017b). The Influence of Product Quality, Service Quality and Price to Purchase Decision of SGM Bunda Milk (Study on PT. Sarihusada Generasi Mahardika Region Jakarta, South Tangerang District). Scholars Bulletin. https://doi.org/10.21276/sb

Ardiansyah, M. A. (2012). Pengaruh Kualitas Produk Terhadap Minat Pembelian Serta Dampaknya Terhadap Proses Keputusan Pembelian J\&C Cookies.

Arikunto, S. (2006). Metode Penelitian Kualitatif. Bumi Aksara.

Balter, S. (2015). Multi-Channel Marketing.

Bimaruci, H., Agung Hudaya, \& Hapzi Ali. (2020). MODEL OF CONSUMER TRUST ON TRAVEL AGENT ONLINE: ANALYSIS OF PERCEIVED USEFULNESS AND SECURITY ON RE-PURCHASE INTERESTS (CASE STUDY TIKET.COM). Dinasti International Journal of Economics, Finance \& Accounting. https://doi.org/10.38035/dijefa.v1i1.227

Brata, B. H., Husani, S., \& Ali, H. (2017). The Importance of Quality Products, Price, Promotion, and Location to Product Purcese Decision on Nitchi At PT. Jaya Swarasa Agung in Central Jakarta. Saudi Journal of Business and Management Studies. https://doi.org/10.21276/sjbms

Chen, S. (2015). Multichannel Marketing: a Generalized Framework, and the Antecendents and Consequences of Its Implementation. March, 1-124.

Citra Kunia putri dan trisna insan Noor, 2011. (2013). 済無No Title No Title. Analisis Pendapatan Dan Tingkat Kesejahteraan Rumah Tangga Petani, 53(9), 1689-1699.

Desfiandi, A., Desfiandi, A., \& Ali, H. (2017). Composite Stock Price Index (IHSG) Macro Factor in Investment in Stock (Equity Funds). International Journal of Economics and Financial Issues.

Desfiandi, A., Fionita, I., \& Ali, H. (2017). Implementation of the information systems and the creative economy for the competitive advantages on tourism in the province of Lampung. International Journal of Economic Research.

Dewan Pers. (2017). Mendorong Profesionalisme Pers melalui verifikasi Perusahaan Pers. Jurnal Dewan Pers, 14.

Dewi, I. K., \& Kusumawati, A. (2018). Pelanggan Bisnis Online ( Survei pada Mahasiswa Fakultas Ilmu Administrasi Universitas Brawijaya Angkatan 2013 / 2014 Konsumen Traveloka ). Jurnal Administrasi Bisnis, 56(1), 155-163.

Easingwood, C. and Storey, C. (1996). "The Value of Multi-Channel Distribution Systems in the Financial Services Sector." The Services Industries Journal,Vol. 16, N, 223-241.

Endhar Widjaya Putra, 2014. (2014). Pengaruh Diskon Terhadap Minat Beli Serta Dampaknya pada Keputusan Pembelian (Survey pada Konsumen yang Membeli Produk Diskon di Matahari Department Store Pasar Besar Malang). Engaruh Diskon Terhadap Minat Beli Serta Dampaknya Pada Keputusan Pembelian (Survey Pada Konsumen Yang Membeli Produk Diskon Di Matahari Department Store Pasar Besar Malang).

Ghristian, I. D. (2016). Citra Merek, Dan Iklan Terhadap Minat Beli Celana Jeans Levi 's Di Surabaya. Journal of Business and Banking, 5(2), 319-336. 
https://doi.org/10.14414/jbb.v5i2.552

Hobmeier, M. (2001). "Professional multichannel management."

Ikhsani, K., \& Ali, D. H. (2017). Keputusan Pembelian: Analisis Kualitas Produk, Harga dan

Brand Awareness (Studi Kasus Produk Teh Botol Sosro di Giant Mall Permata Tangerang). In Jurnal SWOT.

Kelly, M. (2004). "One to many, through many."

Kotler, P. \& Keller, K. (2009). Marketing Management, 13th Edition. Prentice Hall.

Kotler, P. and G. A. (2012). Prinsip-prinsip Pemasaran (Edisi. 13.). Erlangga.

Kotler, Ph. (2000). Marketing Management, 10th International Edition, Prentice Hall, Upper Saddle River, pp. 507-509.

Kotler, Philip. (2007). Manajemen Pemasaran, Jilid 2, Edisi 12, New Jersey: PT Indeks. PT Indeks.

Kotler Philip \& Armstrong. (2008). Principles of Marketing Kotler \& Amstrong Pearson Education.

Limakrisna, N., \& Ali, H. (2016). Model of Customer Satisfaction: Empirical Study At Fast Food Restaurants in Bandung. International Journal of Business and Commerce.

M, A., \& Ali, H. (2017). MODEL KEPUASAN PELANGGAN: ANALISIS KUALITAS PRODUK DAN KUALITAS LAYANAN TERHADAP CITRA MEREK PADA GIANT CITRA RAYA JAKARTA. Jurnal Manajemen. https://doi.org/10.24912/jm.v21i3.254

Mahendrayasa, A. (2014). PENGARUH WORD OF MOUTH TERHADAP MINAT BELI SERTA DAMPAKNYA PADA KEPUTUSAN PEMBELIAN (Survei pada Mahasiswa Pengguna Kartu Selular GSM âIM3â Angkatan 2011/2012 dan 2012/2013 Fakultas Ilmu Administrasi Universitas Brawijaya Malang). Jurnal Administrasi Bisnis S1 Universitas Brawijaya, 12(1), 82799.

Maisah, \& Ali, H. (2020). Entrepreneurship culture development process: Implementation of Islamic education values in the Batik Jambi (case study in Seberang Jambi community). Talent Development and Excellence.

Mappesona, H., Ikhsani, K., \& Ali, H. (2020). Customer purchase decision model, supply chain management and customer satisfaction: Product quality and promotion analysis. International Journal of Supply Chain Management.

Montjai, O., Tewal, B., \& Lengkong, P. . V. (2014). Motivasi, Sikap, Dan Minat Beli Konsumen Pengaruhnya Terhadap Keputusan Pembelian Sepeda Motor Yamaha Pt. Hasjrat Abadi Sentral Yamaha Manado.

Mowen, J. C. (1987). Consumer Behavior : Second Edition. MacMillan.

Novansa, Hafizh, Ali, H. (2017). Purchase Decision Model: Analysis of Brand Image, Brand Awareness and Price (Case Study SMECO Indonesia SME products). Saudi Journal of Humanities and Social Sciences.

Prihartono, \& Ali, H. (2020). The promises ethics and marketing concept strategy as a competitive advantage on private higher education (A survey on perception of product attributes and promotion mix in Indonesia). Talent Development and Excellence.

Pucci, T., Casprini, E., Nosi, C., \& Zanni, L. (2019). Does social media usage affect online purchasing intention for wine? The moderating role of subjective and objective knowledge. British Food Journal, 121(2), 275-288. https://doi.org/10.1108/BFJ-062018-0400

Rahma, E. S. (2007). Analisis engarh Kalias Merek Terhadap Minat Beli dan dampaknya Pada Keputusan Pembelian (Studi Pada Pengguna Telepon Seluler Merek Sony Ericson Di Kota Semarang),.

Rangaswamy, A. \&Van Bruggen, G. (2005). Opportunities and challenges in multichannel 
marketing: An introduction to the special issue. Journal of Interactive Marketing.

Richardo, Hussin, M., Bin Norman, M. H., \& Ali, H. (2020). A student loyalty model: Promotion, products, and registration decision analysis-Case study of griya english fun learning at the tutoring institute in wonosobo central Java. International Journal of Innovation, Creativity and Change.

Rivan Kojongian, Joyce Lapian, H. T. P. (2019). Analisis Pengaruh Word Of Mouth, Iklan Dan Citra Merek Terhadap Keputusan Pembelian Melalui Minat Beli Sebagai Variabel Intervening Pada Smartphone Xiaomi Manado Rivan. Jurnal Riset Bisnis \& Manajemen, 7.

Riyanto, S., Adila, L., \& Ali, H. (2017). The Effect of Incentives And Job Enthusiasm To Productivity of Go-Jek Driver At PT . Go-Jek Indonesia. Journal of Research in Business and Management.

Rollo, C. (2004). "Seniors, Teens, and Everyone Tween: Selecting service channels to fit customer demographics."

Romli, A. S. M. (2012). Jurnalistik online : panduan praktis mengelola media online (Irwan Kurniawan (ed.)). Nuansa Cendekia.

Schijns, J. M. C., \& Nederland, O. U. (2014). Multi-channel Management : Getting it Right! Multi-channel Management: Getting it Right! Jos Schijns Kees Groenewoud. June 2006.

Schögel, M. and Sauer, A. (2002). "Multi-Channel Marketing - Die Königsdisziplin im CRM."

Setiadi, N. J. (2003). Perilaku Konsumen. Edisi Revisi. Prenadademia Group.

Sitio, T., \& Ali, H. (2019). Patient Satisfaction Model and Patient Loyalty: Analysis of Service Quality and Facility (Case Study at Rawamangun Special Surgery Hospital). Scholars Bulletin. https://doi.org/10.36348/sb.2019.v05i10.002

Sivaram, M., Munawar, N. A., \& Ali, H. (2020). DETERMINATION OF PURCHASE INTENT DETERMINATION OF PURCHASE INTENTION THROUGH BRAND AWARENESS AND PERCEIVED QUALITY (Case Study: For consumers PT. Sentosa Santosa Finance Tangerang area). Dinasti International Journal of Management Science. https://doi.org/10.31933/dijms.v1i2.71

Stojković, D., Lovreta, S., \& Bogetić, Z. (2016). Multichannel strategy - The dominant approach in modern retailing. Economic Annals, 61(209), 105-127. https://doi.org/10.2298/EKA1609105S

Suharno \& Yudi Sutarso. (2010). Marketing in Practice. Graha Ilmu.

Sundalangi, M., Mandey, S. L., Jorie, R. J., Produk, K., Produk, K., Iklan, D. T., Potongan, D. A. N., \& Terhadap, H. (2014). KUALITAS PRODUK, DAYA TARIK IKLAN, DAN POTONGAN HARGA TERHADAP MINAT BELI KONSUMEN PADA PIZZA HUT MANADO. KUALITAS PRODUK, DAYA TARIK IKLAN, DAN POTONGAN HARGA TERHADAP MINAT BELI KONSUMEN PADA PIZZA HUT MANADO, 2(1), 313-324.

Thanh Nguyen, P., Ali, H., \& Agung Hudaya. (2019). MODEL BUYING DECISION AND REPEAT PURCHASE: PRODUCT QUALITY ANALYSIS (Case Study of Bank Permata Syariah Jakarta KPR Financing Customers). Dinasti International Journal of Management Science. https://doi.org/10.31933/dijms.v1i1.29

Toto Handiman, U., \& Ali, H. (2019). The Influence of Brand Knowledge and Brand Relationship On Purchase Decision Through Brand Attachment. In International Journal of Business Marketing and Management (IJBMM).

Verhagen, T., \& van Dolen, W. (2009). Online purchase intentions: A multi-channel store image perspective. Information and Management, 46(2), 77-82. 
https://doi.org/10.1016/j.im.2008.12.001

Widayati, C.C., Ali, H., Permana, D., \& Nugroho, A. (2020). The role of destination image on visiting decisions through word of mouth in urban tourism in Yogyakarta. International Journal of Innovation, Creativity and Change, 12(3).

Widayati, Christina Catur, Ali, H., Permana, D., \& Nugroho, A. (2020). The role of destination image on visiting decisions through word of mouth in urban tourism in Yogyakarta. International Journal of Innovation, Creativity and Change.

Yunita, D., \& Ali, H. (2017). Model of Purchasing Decision ( Renting ) of Generator Set: Analysis of Product Quality, Price an Service at PT . Hartekprima Listrindo. Economics, Business and Management. https://doi.org/10.21276/sjebm.2017.4.11.12 